\title{
PERAN KERJASAMA TIM \\ DALAM PENANGGULANGAN KEBARAN HUTAN DAN LAHAN
}

\author{
Junaidi \\ Widya Iswara Badan Pengembangan Sumber Daya Manusia Provinsi Riau \\ JL. Ronggowarsito No $14 \mathrm{Kec}$. Sail, Pekan Baru Provinsi Riau \\ E-mail : junjoen011@yahoo.co.id
}

\begin{abstract}
Land and forest fires (Karlahut) pose a great impact in terms of environment, education, politics, economics, health, inter-state relations and the image of Indonesia in the eyes of the world. As a result of Karlahut has damaged millions of hectares of land and forests that have an impact on material and immaterial losses are very large. Through the Minister of Environment and Forestry of the Republic of Indonesia Number P.32 / MenLHK / Secretariat / Kum.1 / 3/2016 have set a system control forest fires. Teamwork is a critical importance of a system of land and forest fire control. Tampa team that is compact and harmonious then the purpose of the system already built will be difficult to accomplish.
\end{abstract}

Keyword : karlahut, tim, staekholder.

\section{PENDAHULUAN}

Hutan menurut Undang-Undang Republik Indonesia Nomor 41 Tahun 1999 adalah suatu kesatuan ekosistem berupa hamparan lahan berisi sumber daya alam hayati yang didominasi pepohonan dalam persekutuan alam lingkungannya, yang satu dengan lainnya tidak dapat dipisahkan. Sesuai dengan manfaatnya, hutan merupakan sumber oksigen $\left(\mathrm{O}_{2}\right)$ yang sangat dibutuhkan oleh manusia dan bagi seluruh mahluk hidup yang ada di bumi, serta sebagai salah satu media yang dapat menyerap karbon dioksida $\left(\mathrm{CO}_{2}\right)$ yang beredar di dalam udara. Oleh karena itu peranan hutan sangatlah penting sebagai paru-paru dunia sehingga keberadaannya harus terus dapat terjaga.

Kebakaran lahan dan hutan (Karlahut) menimbulkan dampak yang besar dari segi lingkungan, pendidikan, politik, ekonomi, kesehatan, hubungan antar negara dan citra Indonesia di mata dunia. Akibat dari Karlahut telah merusak jutaan hektar lahan dan hutan yang berdampak terhadap kerugian materil dan imateril yang sangat besar. Menurut Tempo.Co, Jakarta, studi terbaru yang dilakukan oleh 12 peneliti asal Universitas Harvard dan Columbia 
menyatakan ada 100.300 kasus kematian yang disebabkan oleh kebakaran hutan di Indonesia pada September-Oktober 2015. Dari jumlah itu diperkirakan 91.600 kematian ada di Indonesia, 2.200 kasus kematian di Singapura, dan 6.500 kasus kematian di Malaysia. Kerugian secara finansial Kebakaran hutan dan lahan (Karhutla) pada Juni hingga Oktober 2015 sebesar Rp 221 triliun (REPUBLIKA.CO.ID, JAKARTA). Hal ini menjadi perhatian serius oleh berbagai pihak, sehingga pemerintah melakukan berbagai upaya untuk menanggulangi kebakaran lahan dan hutan di Indonesia. Dalam sistem penanggulangan kebakaran hutan akan banyak melibatkan berbagai stakeholder yang saling berkoordinasi antara satu dengan yang lainnya dan didalam perjalanannya tidak menutup kemungkinan terjadi masalah atau konflik. Agar pelaksanaan pengendalian kebakaran hutan dan lahan dapat berjalan dengan optimal maka diperlukan kerjasama tim yang baik. Penelitian ini bertujuan untuk mengetahui sistem pengendalian kebakaran lahan dan hutan di indonesia dan peran kerjasama tim dalam penanggulangan kebakaran hutan dan lahan tersebut.

\section{METODE PENELITIAN}

Kajian dalam tulisan ini menggunakan pendekatan kualitatif deskriptif dimana data yang diperoleh berasal dari sutudi kepustakaan dan disajikan secara sistematis untuk memperoleh gambaran tentang sistem pengendalian kebakaran hutan dan lahan di indonesia dan bagaimana peran kerjasama tim dalam sistem penanggulangan kebakaran tersebut.

\section{HASIL DAN PEMBAHASAN}

\section{Sistem Pengendalian Kebakaran Hutan dan Lahan di Indonesia}

Upaya pencehan kebakaran hutan dan lahan di Indonesia diatur melalui Peraturan Menteri Lingkungan Hidup dan Kehutanan Republik Indonesia

Nomor

P.32/MenLHK/Setjen/Kum.1/3/2016

tentang Pengendalian Kebakaran Hutan dan Lahan. Pengendalian Kebakaran Hutan dan Lahan yang disebut dalkarhutla meliputi usaha/kegiatan/tindakan

pengorganisasian, pengelolaaan sumberdaya manusia dan sarana prasarana serta operasional pencegahan, pemadaman, penanganan pasca kebakaran, dukungan evakuasi 
dan penyelamatan, dan dukungan manajemen pengendalian kebakaran hutan dan/atau lahan. Dalam pelaksanaanya, sistem penanggulangan kebakaran hutan dan lahan dilakukan melalui organisasiorganisasi penanggulangan kebakaran hutan dan lahan yang di bentuk oleh pemerintah di tingkat pusat, provinsi, maupun kabuapten/kota. Untuk lebih jelasnya berikut akan di sajikan organisasi-organisasi yang dimaksud.

\section{Organisasi Pengendalian Kebakaran} Hutan dan Lahan Tingkat Pemerintah Organisasi

Dalkarhutla

Pemerintah bertanggung jawab terhadap upaya Dalkarhutla secara nasional, terdiri dari:

\section{Organisasi Dalkarhutla yang} berfungsi koordinatif; Organisasi Dalkarhutla Pemerintah yang berfungsi koordinatif, bersifat adhoc, dilaksanakan oleh Satuan Tugas yang disebut Satgas Pengendali Nasional Penanganan Kebakaran Hutan dan Lahan, ditetapkan oleh Menteri. diketuai oleh Menteri dan beranggotakan sekurang-kurangnya Kepala Badan Nasional Penanggulangan Bencana (BNPB), Menteri Agraria dan Tata
Ruang/BPN, Menteri Kesehatan, Panglima TNI, Kepala Kepolisian Negara Republik Indonesia, Kepala Badan Meteorologi, Klimatologi dan Geofisika, Kepala Badan Informasi Geospasial, Kepala Lembaga Penerbangan dan Antariksa Nasional dan atau Kementerian/Lembaga terkait Dalkarhutla lainnya sesuai tingkat kepentingan dan kewenangannya. berkedudukan di Kementerian Lingkungan Hidup dan Kehutanan. Fungsi Satgas Pengendali Nasional Penanganan Kebakaran Hutan dan Lahan adalah mengkoordinasikan perencanaan, pengorganisasian, operasional, pengawasan dan evaluasi dalam setiap usaha Dalkarhutla

2. Organisasi Dalkarhutla yang berfungsi operasional, Organisasi Dalkarhutla Pemerintah yang berfungsi operasional dilaksanakan oleh Brigdalkarhutla Pemerintah yang disebut Manggala Agni. Manggala Agni terdiri atas:

a. Manggala Agni Pusat; Manggala Agni Pusat berkedudukan di Kementerian Lingkungan Hidup dan Kehutanan, dipimpin oleh 
Direktur dan bertanggung jawab kepada Direktur Jenderal.

b. Manggala Agni Regional; Manggala Agni Regional dipimpin oleh Kepala Brigdalkarhutla Unit Pelaksana Teknis Pusat dan bertanggung jawab kepada Direktur Jenderal.

c. Daops Manggala Agni.Daops Manggala Agni sebagai pelaksana operasional Dalkarhutla, dipimpin oleh Kepala Daops, di bawah pembina teknis Manggala Agni Regional dan bertanggung jawab kepada Manggala Agni Pusat. Daops Manggala Agni terdiri dari dua atau lebih Regu Manggala Agni, yang dipimpin oleh Kepala Regu dan bertanggungjawab kepada Kepala Daops Manggala Agni.
Ketentuan lebih lanjut mengenai Organisasi dan Wilayah Kerja Daops Manggala Agni sebagaimana dimaksud pada ayat (5) diatur dengan Peraturan Direktur Jenderal (Pasal 11 ayat 6 Permen LHK No.P.32/ Menlhk/Setjen/ Kum.1/3/2016), mengingat penting dan daruratnya penanggulangan karhutla semoga segera diregulasikan.

Di Kementerian Lingkungan Hidup dan Kehutanan tugas penyiapan perumusan, pelaksanaan, koordinasi dan sinkronisasi kebijakan, bimbingan teknis dan evaluasi bimbingan teknis, dan supervisi pelaksanaan urusan di daerah bidang pengendalian kebakaran hutan dan lahan dilaksanakan oleh Direktorat Pengendalian Kebakaran Hutan dan Lahan Direktorat Jenderal Pengendalian Perubahan Iklim dengan struktur organisasi sbb: 


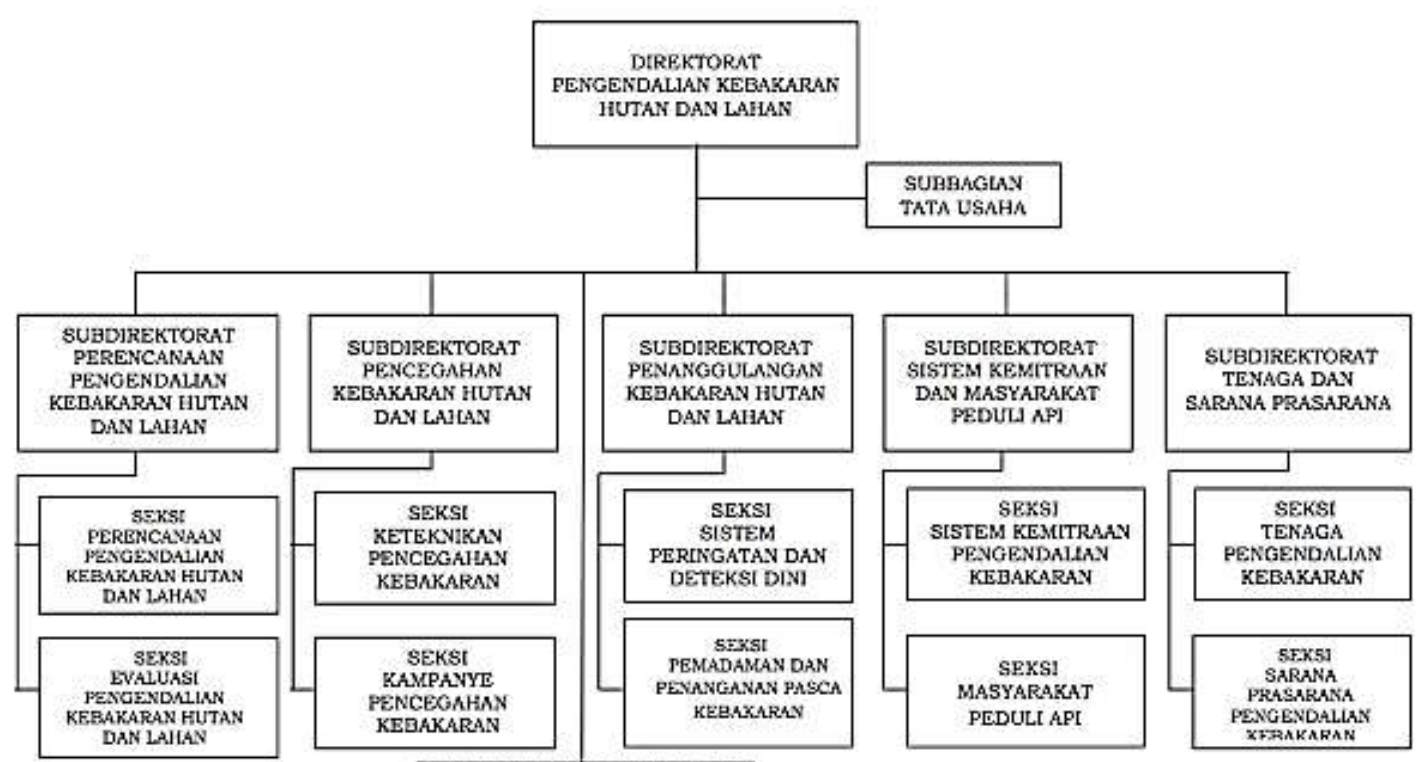

\section{Gambar 1. Struktur Organisasi Direktorat Kebakaran Hutan dan Lahan}

\section{Organisasi Pengendalian Kebakaran} Hutan Dan Lahan Pemerintah Provinsi

\section{Organisasi Dalkarhutla}

Pemerintah Provinsi dapat dibentuk atau menunjuk organisasi yang bertanggung jawab terhadap dalkarhutla pada tingkat provinsi, terdiri dari:

1. Organisasi Dalkarhutla yang berfungsi koordinatif, Organisasi Dalkarhutla Pemerintah Provinsi yang berfungsi koordinatif bersifat ad-hoc, yang disebut Satgas Pengendali Provinsi Penanganan Kebakaran Hutan dan Lahan. diketuai oleh
Gubernur, sekurang-kurangnya beranggotakan Sekretariat Daerah, Badan Perencanaan Pembangunan Daerah (BAPPEDA), Badan Penanggulangan Bencana Daerah, Badan Lingkungan Hidup Daerah (BLHD), Dinas Teknis bidang Kehutanan, Perkebunan, Pertanian dan/atau Dinas Teknis terkait lainnya, Manggala Agni, Pemerintah Kabupaten/Kota dibawahnya, Pemerintah Provinsi disekitarnya, Kepolisian Daerah, TNI setempat, dan atau instansi terkait Dalkarhutla lainnya sesuai tingkat kepentingan dan kewenangannya. Satgas 
Pengendali Provinsi Penanganan Kebakaran Hutan dan Lahan berkedudukan di Kantor Pemerintah Provinsi yang bersangkutan, memiliki fungsi mengkoordinasikan perencanaan, pengorganisasian, operasional, pengawasan dan evaluasi dalam setiap usaha Dalkarhutla. Satgas Pengendali Provinsi Penanganan Kebakaran Hutan dan Lahan wajib membentuk kesekretariatan yang disebut Posko Krisis Kebakaran Hutan dan Lahan Provinsi.

2. Organisasi Dalkahutla Pemerintah Provinsi yang berfungsi operasional, Organisasi Dalkahutla Pemerintah Provinsi yang berfungsi operasional sebagaimana dilaksanakan oleh Satuan Kerja Dalkarhutla, dipimpin Kepala Satuan Kerja Dalkarhutla, dan bertanggung jawab kepada Gubernur. Satuan Kerja Dalkarhutla ditetapkan oleh Gubernur. Bertugas menjalankan perencanaan, pengorganisasian, operasional, pengawasan dan evaluasi dalam setiap usaha Dalkarhutla.

\section{Organisasi Pengendalian Kebakaran} Hutan dan Lahan Pemerintah Kabupaten/Kota

Organisasi

Dalkahutla

Pemerintah Kabupaten/Kota bersifat adhoc, yang disebut Satgas Pengendali Kabupaten/Kota

Penanganan Kebakaran Hutan dan Lahan. ditetapkan oleh Bupati/Walikota. diketuai oleh Bupati/Walikota, sekurang-kurangnya beranggotakan Sekretariat Daerah, Badan Perencanaan Pembangunan Daerah (BAPPEDA), Badan Penanggulangan Bencana Daerah, Badan Lingkungan Hidup Daerah (BLHD), Perkebunan, Pertanian dan/atau Dinas Teknis terkait lainnya, Masyarakat Peduli Api (MPA) setempat, Manggala Agni, Kecamatan dan Desa dibawahnya,

Pemerintah

Kabupaten/Kota disekitarnya, Kepolisian setempat, TNI setempat, dan atau instansi terkait dalkarhutla lainnya sesuai tingkat kepentingan dan kewenangannya. Satgas Pengendali Kabupaten/Kota Penanganan Kebakaran Hutan dan Lahan berkedudukan di Kantor Pemerintah Kabupaten/Kota bersangkutan, yang memiliki fungsi mengkoordinasikan perencanaan, pengorganisasian, operasional, pengawasan dan evaluasi 
dalam setiap usaha Dalkarhutla di wilayahnya. Satgas wajib membentuk Kesekretariatan, yang disebut Posko Krisis Kebakaran Hutan dan LahanKabupaten/Kota. Hal-hal yang bersifat operasional, Pemerintah Kabupaten/Kota membebankan pelaksanaannya kepada masing-masing Kesatuan Pengelolaan Hutan, Kesatuan Pemangkuan Hutan, Perum Perhutani, Pemegang Izin Pemanfaatan Hutan, Pemegang Izin Pinjam Pakai Kawasan Hutan, Pemegang Izin Hutan Kemasyarakatan, dan Pemegang Izin Hutan Desa.

Organisasi Pengendalian Kebakaran Hutan dana lahan Tingkat Pengelolaan

Setiap Unit Pelaksana Teknis Daerah Pengendalian Kebakaran Hutan dan Lahan, Unit Pelaksana Teknis Daerah Taman Hutan Raya, Kesatuan Pengelolaan Hutan Produksi, Kesatuan Pengelolaan Hutan Lindung, Kesatuan Pengelolaan Hutan Konservasi, Kesatuan Pemangkuan Hutan, Perum Perhutani, dan Pemegang Izin Usaha Pemanfaatan Hasil Hutan wajib membentuk Organisasi Brigdalkarhutla (Pasal 18 Permen LHK No.P.32/
Menlhk/Setjen/ Kum.1/3/2016), jadi organisasi Brigdalkrhutla terdiri dari:

1. Brigdalkar UPTD Pengendalian Kebakaran Hutan dan Lahan;

2. Brigdalkar UPTD Taman Hutan Raya;

3. Brigdalkar KPHP atau KPHL atau KPHK atau KPH Perum Perhutani;

4. Brigdalkar IUPHHK atau IUPHHBK atau IUPHHK-RE dalam hutan alam pada hutan produksi;

5. Brigdalkar IUPHHK atau IUPHHBK dalam HTI dan HTHR; dan

6. Brigdalkar IPPKH pada hutan lindung dan hutan produksi untuk kegiatan pertambangan.

Setiap

organisasi

Brigdalkarhutla sekurang-kurangnya mempunyai perangkat organisasi dan tugas pokok meliputi:

1. Kepala Brigade; yang dalam pelaksanaannya dapat dirangkap oleh Kepala Unit Pengelolaan pada tingkat lapangan atau pejabat yang ditunjuk, bertanggung jawab kepada Kepala di tingkat pengelolaan, melaksanakan tugas di bidang perencanaan, pengorganisasian, 
operasional, pengawasan dan evaluasi dalam setiap usaha Dalkarhutla di wilayah kerjanya;

2. Sekretaris Brigade; bertanggung jawab kepada Kepala Brigade, melaksanakan tugas di bidang dukungan manajemen;

3. Koordinator Pencegahan Kebakaran Hutan dan Lahan; bertanggung jawab kepada Kepala Brigade, melaksanakan tugas perencanaan, pengorganisasian, operasional, pengawasan dan evaluasi di bidang pemberdayaan masyarakat, penyadartahuan, pengurangan resiko, peningkatan kapasitas kelembagaan, pelaksanaan patroli, dan peringatan dini;
4. Koordinator Pemadaman dan Penanganan Pasca Kebakaran; bertanggung jawab kepada Kepala Brigade, melaksanakan tugas perencanaan, pengorganisasian, operasional, pengawasan dan evaluasi di bidang deteksi dini, groundcek, pemadaman awal dan lanjutan, inventarisasi dan monitoring areal bekas kebakaran, koordinasi penanganan pasca kebakaran, dukungan evakuasi dan penyelamatan; dan

5. Kepala Regu; bertanggung jawab kepada Kepala Brigade, melaksanakan tugas operasional Dalkarhutla di lapangan. 


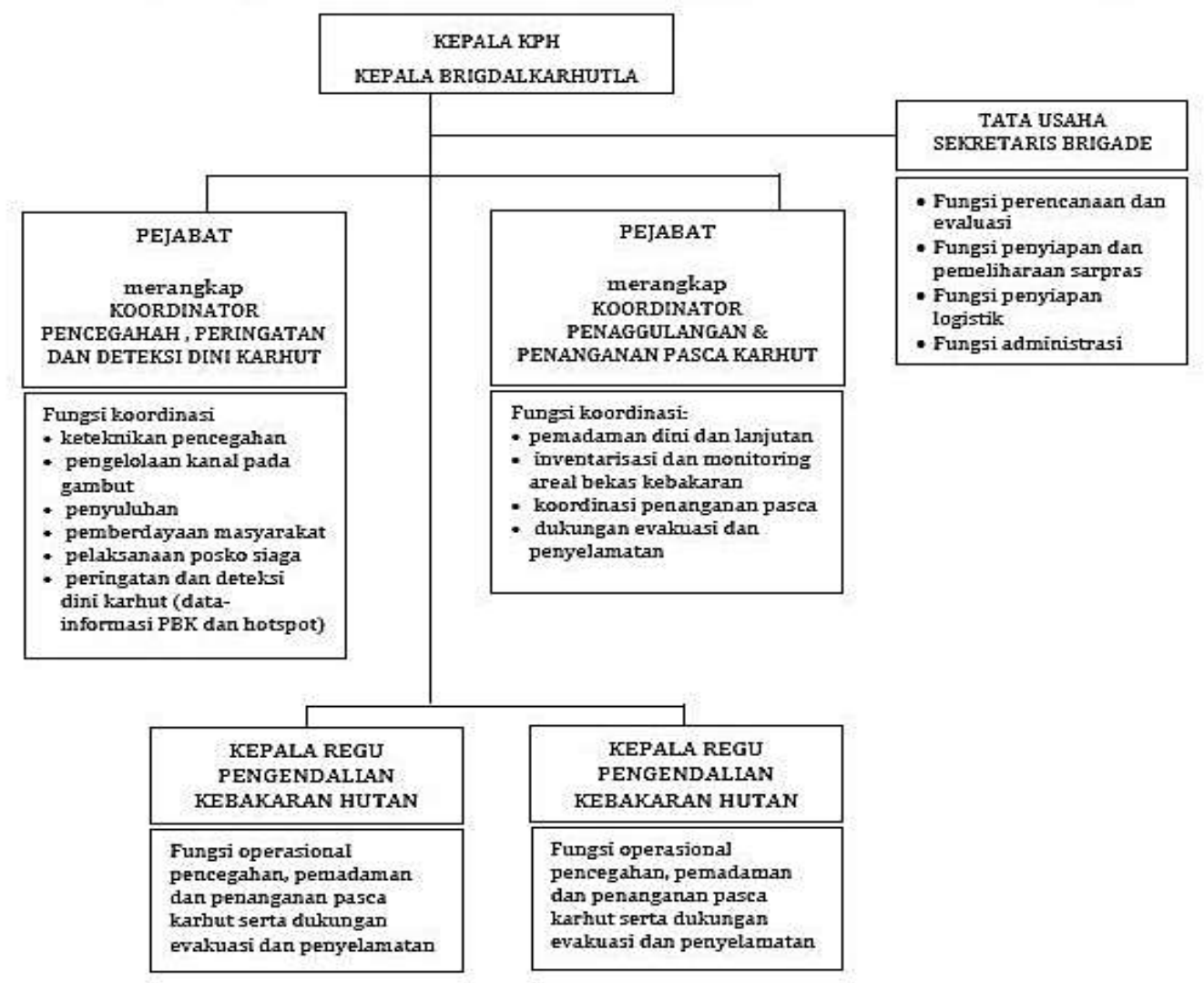

Gambar 2. Struktur Organisasi Brigade Pengendalian Kebakaran Hutan KPH

Setiap Brigdalkarhutla dapat diberi identitas organisasi dalam bentuk antara lain nama, bendera, pataka, atau maskot, yang ditetapkan oleh masingmasing unit pengelola.

\section{Masyarakat Peduli Api (MPA)}

Setiap Pemegang IUPK atau IUPJL atau IPHHBK pada hutan lindung dan hutan produksi; dan pemegang IPHHK dalam hutan alam pada hutan produksi dan HTR;Pemegang Izin Pinjam Pakai Kawasan Hutan untuk kegiatan non pertambangan;Pengelola Hutan Kemasyarakatan;Pengelola
Hutan Desa;Penanggung jawab Hutan Adat; Pemilik Hutan Hak;Pemegang KHDTK; dan Kelompok tani sekitar hutan atau desa konservasi atau kampung iklim atau desa wisata berbasis ekosistem hutan; wajib memfasilitasi organisasi kelompokkelompok Masyarakat Peduli Api (MPA).

Dalam satu MPA sekurangkurangnya terdiri dari 2 regu, masingmasing regu terdiri dari 15 anggota masyarakat setempat dalam satu desa. Pembentukan dan pembinaan MPA, dilakukan bersama dengan kesatuan 
pengelolaan hutan dan/atau Manggala Agni terdekat.

Setiap organisasi MPA sekurang-kurangnya mempunyai perangkat organisasi dan tugas, meliputi:

1. Ketua Masyarakat Peduli Api (MPA); melaksanakan tugas perencanaan, pengorganisasian, operasional, pengawasan dan evaluasi dalam setiap usaha Dalkarhutla di desanya;

2. Sekretaris merangkap Bendahara; melaksanakan tugas untuk mengelola administrasi keuangan dan tugas-tugas kesekretariatan;

3. Kepala Regu; melaksanakan tugas operasional dalkarhutla.

\section{Peran Kerjasama Tim Dalam Penanggulagan Kebakaran Hutan dan Lahan}

Hasil kerja atau bekerja secara tim biasanya akan lebih efektif dari pada bekerja secara perorangan, karena hasil kerja dan pemikiran lebih dari satu orang pasti lebih baik dari pada hasil pemikiran satu orang saja. Bekerjasama dalam Tim ini selalu dilakukan baik dalam suatu unit kerja maupun dalam kegiatan organisasi atau kegiatan sosial kemasyarakatan lainnya. Tim merupakan gabungan beberapa orang yang terikat oleh sistem dalam rangka mencapai tujuan. Menurut Robert B. Maddux dalam bukunya "Team Building "menyebutkan bahwa beberapa manfaat yang diperoleh dengan membangun tim yang efektik diantaranya adalah ; (1) Bila Sasaran itu realistis pasti dapat dicapai secara optimal; (2) Setiap anggota team memiliki komitmen untuk saling mendukung dan saling membantu; (3) Komunikasi bersifat terbuka sehingga setiap anggota akan terdorong untuk memikirkan permasalahan yang ada; (4) Pemecahan masalah lebih efektif; (5) Umpan balik kinerja yang dapat menjadi acuan anggota apakah kinerjanya sesuai dengan tujuan tim ; (6) Konflik diterima sebagai hal yang wajar, karena suatu wahana untuk penyelesaian masalah; (7) Adanya Keseimbangan tercapainya produktivitas tim dengan pemenuhan kebutuhan individu. Dalam sistem penanggulagan kebakaran hutan dan lahan banyak melibatkan berbagai stakeholder, mulai dari pusat sampai ke daerah. Masing-masing stakeholder tersebut mempunyai peran dan funginya masing-masing, sehingga didalam pelaksanaan upaya penanggulangan 
kebakaran lahan dan hutan tidak menutup kemungkinan akan terjadi berbagai hambatan. Untuk itu diperlukan kerjasama yang solid dan sinergisitas antara berbagai stakeholder yang terlibat, sehingga tujuan dari program penanggulangan kebakaran hutan dan lahan dapat tercapat dengan optimal. Bila di lihat dari manfaat kerjasama tim menurut Robert B. Maddux, maka dapat kita katakan bahwa kerjasama tim sangat memiliki peran penting dalam capaian penanggulangan kebakaran hutan dan lahan di Indonesia.

\section{KESIMPULAN}

Hutan merupakan suatu kesatuan ekosistem berupa hamparan lahan berisi sumber daya alam hayati yang didominasi pepohonan dalam persekutuan alam lingkungannya, yang satu dengan lainnya tidak dapat dipisahkan, dan sekaligus merupakan karunia Tuhan Yang Maha Esa yang yang tak terhingga manfaatnya untuk kesejahteraan umat manusia, sehingga keberdaannya perlu di jaga dan di pertahankan keberadaannya. Melalui kerjasama tim yang kompak dan harmonis, maka penanggulangan kebakaran hutan dan lahan di Indonesia dapat berjalan dengan baik.

\section{DAFTAR PUSTAKA}

Countryman CM. 1975. The Nature of Heat. Heat-lts role in wildland firepart 1. California: Unnumbered publication, USDA For. Serv, Pacifik Southwest Forestry and Range Experiment Station.

Republika,co.id,2015.Jakarta.

Robert B. Maddux, Team Building, Terampil Membangun Tim Handal, Edisi ke dua, Dialihbahasakan oleh KristiyabudiP. Hananto, S.Psi.,M.M., PT. Erlangga, Surabaya,2001.

Suratmo FG. 1999. Pedoman Nasional Perlindungan Hutan Terhadap Kebakaran: Pengendalian Kebakaran Hutan Terpadu di Indonesia Buku I. ITTO, CFC, IPB, Various.

Syaufina L. 2008. Kebakaran Hutan dan Lahan di Indonesia. Malang: Bayumedia.

Tacconi. 2003. Kebakaran Hutan di Indonesia: Penyebab, Biaya dan Implikasi Kebijakan. Bogor: CIFOR.

Tempo.Co, 2015.Jakarta.

Peraturan Menteri Lingkungan Hidup dan Kehutanan Republik Indonesia No.P. 32/MenLHK/setjen/Kum.1/3/2016. Tentang Pengendalian Kebakaran Hutan dan Lahan. 